\title{
GOOD CORPORATE GOVERNANCE DAN PENGARUHNYA TERHADAP NILAI PERUSAHAAN MELALUI CORPORATE SOCIAL RESPONSIBILITY DISCLOSURE
}

\author{
I Gusti Ayu Purnamawati, Gede Adi Yuniarta, Putu Ria Astria
}

Departemen Akuntansi Fakultas Ekonomi dan Bisnis Universitas Pendidikan Ganesha Jl. Udayana (Kampus Tengah) Singaraja-Bali, 81116, Indonesia

\begin{tabular}{|c|c|}
\hline & ABSTRACT \\
\hline $\begin{array}{l}\text { Keyword: } \\
\text { Corporate Social } \\
\text { Responsibility } \\
\text { Disclosure, Good } \\
\text { Corporate Gover- } \\
\text { nance, Tobin's Q } \\
\text { JEL Classification: } \\
\text { G34, G32, M14 }\end{array}$ & $\begin{array}{l}\text { This research explained the relationship between Good Corporate Governance mechanism to } \\
\text { company's value, and the extent disclosure of Corporate Social Responsibility as moderation } \\
\text { variable. Hierarchical regression analysis was used to examine modernization impact in the rela- } \\
\text { tionship between dependent and independent variable. Sample gathering was undertaken from } \\
2012 \text { to 2014. Tobin's Q was used to assess the company's value. Whereas Good Corporate } \\
\text { Governance mechanism that was proxy by the number of managerial ownership and institutional } \\
\text { ownership quantity was taken from ownership scale existed in company financial report. Extent } \\
\text { measurement of Corporate Social Responsibility expressing was carried out by calculating each } \\
\text { company's CSR Index. This research used } 44 \text { samples of manufacturing companies meeting the } \\
\text { criteria of purposive sampling. The testing of moderation effect and the main effect in the research } \\
\text { was done using hierarchical regression analysis. The result showed that there were positive and } \\
\text { significant relationship between GCG mechanism and company value, whereas between CSR } \\
\text { extent disclosure and company value there was insignificant result. For examining the moderation } \\
\text { impacts, CSR extent disclosure succeeded to moderate the relationship between managerial owner- } \\
\text { ship and company value, but the extent of CSR expression did not succed in moderating the } \\
\text { relationship between institutional ownership and company value. }\end{array}$ \\
\hline
\end{tabular}

Kata Kunci:

Pengungkapan tanggung jawab sosial perusahaan, tatakelola perusahaan, Tobin's $Q$

\begin{abstract}
ABSTRAK
Penelitian ini menjelaskan hubungan antara mekanisme Good Corporate Governance, dengan nilai perusahaan, dan luas pengungkapan Corporate Social Responsibility sebagai variabel pemoderasi. Penelitian ini menggunakan analisis regresi hirarki untuk menguji efek moderasi dalam hubungan antara variabel dependen dan variabel independen. Pengambilan sampel dilakukan dari tahun 2012 sampai tahun 2014. Tobin's Q digunakan untuk mengukur nilai perusahaan. Sedangkan mekanisme GCG yang diproksikan dengan besarnya jumlah kepemilikan manajerial dan kepemilikan institusional diambil dari besar kepemilikan yang terdapat pada laporan keuangan perusahaan. Pengukuran luas pengungkapan CSR dilakukan dengan menghitung CSR Index masing-masing perusahaan. Penelitian ini menggunakan sampel sebanyak 44 perusahaan manufaktur yang memenuhi kriteria purposive sampling. Pengujian efek moderasi dan efek utama di riset dilakukan dengan menggunakan hierarchical regression analysis. Hasil dari penelitian ini menunjukkan bahwa terdapat hubungan yang positif dan signifikan antara mekanisme GCG dengan nilai perusahaan, sedangkan antara luas pengungkapan CSR dengan nilai perusahaan ditemukan hasil yang tidak signifikan. Untuk pengujian efek-efek moderasi, luas pengungkapan CSR berhasil memoderasi hubungan antara kepemilikan manajaerial dengan nilai perusahaan, namun luas pengungkapan CSR tidak berhasil memoderasi hubungan antara kepemilikan institusional dengan nilai perusahaan.
\end{abstract}


Good Corporate Governance (GCG) merupakan salah satu kunci sukses perusahaan untuk tumbuh dan menguntungkan dalam jangka panjang, sekaligus memenangkan persaingan bisnis global. Krisis ekonomi di kawasan Asia dan Amerika Latin diyakini muncul karena kegagalan penerapan GCG (Daniri, 2005). Menilik kembali teori yang melatarbelakangi corporate governance yaitu teori keagenan (Agency Theory), terdapat benturan kepentingan antara principal dan agent. Jensen \& Meckling (1976) menyatakan bahwa kepemilikan institusional dan kepemilikan manajerial memiliki peranan dalam mengatasi masalah keagenan.

Tantangan terkini praktik GCG belum dilaksanakan secara penuh oleh pengusaha. Akibatnya lembaga rating internasional Credit Lyonnaise Securities (2003), menempatkan Indonesia di urutan terbawah dengan skor 1,5 untuk masalah penegakan hukum, 2,5 untuk mekanisme institusional dan budaya corporate governance, dengan total skor 3,2. Sejak awal tahun 2012, pertama kalinya nama-nama dari 50 perusahaan yang terdaftar pada ASEAN CG scorecard diumumkan secara terbuka. Diantara top 50 perusahaan ASEAN, sebanyak 23 perusahaan Thailand berada pada peringkat tertinggi ASEAN CG scorecard; diikuti oleh 11 perusahaan dari Filipina, 8 perusahaan dari Singapura, 6 perusahaan dari Malaysia, dan 2 perusahaan dari Indonesia (Thai Institute of Director, ASEAN CG Scorecard 2015). CG merupakan tata kelola perusahaan yang menjelaskan hubungan antara berbagai partisipan dalam perusahaan yang menentukan arah kinerja perusahaan. Pelaksanaan GCG sangat diperlukan untuk memenuhi kepercayaan masyarakat dan dunia internasional sebagai syarat mutlak bagi perusahaan untuk berkembang dengan baik dan sehat yang tujuan akhirnya untuk mewujudkan shareholder value. Shleifer \& Vishny (1997) yang menyatakan CG berkaitan dengan cara atau mekanisme untuk meyakinkan para pemilik modal dalam memperoleh return yang sesuai dengan investasi yang telah ditanam. Ross et al. (2001) menyatakan bahwa semakin besar proporsi kepemilikan saham pada perusahaan maka manajemen cenderung berusaha lebih giat untuk kepentingan pemegang saham yang tidak lain adalah dirinya sendiri. Kawatu (2009) menyatakan bahwa mekanisme GCG berpengaruh pada nilai perusahaan. Kepemilikan perusahaan oleh institusi akan mendorong pengawasan yang lebih efektif, karena institusi merupakan profesional yang memiliki kemampuan dalam mengevaluasi kinerja perusahaan.

Corporate governance didasari oleh Stakeholder Theory (Freeman, 1984), bahwa perusahaan telah menjadi sangat besar dan menyebabkan masyarakat menjadi sangat pervasive sehingga perusahaan perlu melaksanakan akuntabilitas terhadap berbagai sektor masyarakat dan bukan hanya kepada pemegang sahamnya saja. Saat ini, cara untuk mengukur kinerja CSR adalah melalui laporan kegiatannya, yakni dengan metode content analysis pemangku kepentingan (Daniri, 2009). Gagasan praktik dan pengungkapan CSR berkaitan erat dengan teori kepentingan (Warsono, 2009). Indonesia, pemerintah menegaskan penerapan CSR dengan mengesahkan Undang-undang Nomor 40 tahun 2007 tentang kewajiban pelaksanaan Tanggung Jawab Sosial dan Lingkungan bagi yang menjalankan kegiatan usahanya di bidang dan/atau berkaitan dengan sumber daya alam. Namun masih ada yang menolak, menurut Mahkamah Konstitusi, banyak pemohon mendalilkan, pemberian kewajiban terhadap prinsip CSR telah menimbulkan perlakuan yang tidak sama di muka hukum, karena perusahaan yang bergerak di bidang sumberdaya alam sudah menjalankan kewajibannya berdasarkan undang-undang sektoral yang berlaku (www.csrindonesia.com). Ebert \& Griffin (2003) mendefinisikan Corporate Social Responsibility sebagai usaha perusahaan untuk menyeimbangkan komitmen-komitmennya terhadap kelompok dan individual dalam lingkungan perusahaan tersebut, termasuk didalammya adalah pelanggan, perusahaan lain, para karyawan dan investor. Pene- 


\section{Jurnal Keuangan dan Perbankan | KEUANGAN}

Vol. 21, No. 2, April 2017: 276-286

rapan CSR dalam perusahaan diharapkan selain memiliki komitmen finansial kepada pemilik atau pemegang saham, tapi juga memiliki komitmen sosial terhadap para pihak lain yang berkepentingan (Sandra \& Akhmad, 2011). Darwin (2006) menyatakan bahwa pengungkapan kinerja lingkungan, sosial, dan ekonomi di dalam laporan tahunan atau laporan terpisah adalah untuk mencerminkan tingkat akuntabilitas, responsibilitas, dan transparansi korporat kepada investor dan stakeholders lainnya. Kiroyan (2006). Hal ini mengindikasikan bahwa perusahaan yang menerapkan CSR mengharapkan akan direspon positif oleh para pelaku pasar.

Berdasarkan perspektif ekonomi, perusahaan akan mengungkapkan suatu informasi jika informasi tersebut akan meningkatkan nilai perusahaan (Verrecchia, 1983). Melalui penerapan CSR, diharapkan perusahaan akan memperoleh legitimasi sosial dan memaksimalkan kekuatan keuangannya dalam jangka panjang (Kiroyan, 2006). Hal ini mengindikasikan bahwa perusahaan yang menerapkan CSR mengharapkan akan direspon positif oleh para pelaku pasar. Hal tersebut juga sejalan dengan rekomendasi Global Reporting Initiative yaitu sustainability reporting yang terfokus pada tiga aspek kinerja yaitu ekonomi, lingkungan dan sosial. Ketiga aspek ini dikenal dengan Triple Bottom Line yang terdiri dari profit, people $\mathcal{E}$ planet (3P). Beberapa penelitian sebelumnya, Kampf (2007) menganalisis strategi yang digunakan dalam CSR kepada masyarakat umum melalui internet. Chapple \& Moon (2005) menunjukkan bahwa dibandingkan dengan India, Korea Selatan, Thailand, Singapura, Malaysia dan Filipina, penetrasi pelaporan CSR Indonesia menempati urutan terakhir dengan 24\%. Milton Fredman (Deegan \& Rankin, 1996) yang menilai bahwa pelaksanaan CSR tidak sesuai dengan sifat bisnis di mana tujuan perusahaan adalah untuk memaksimalkan keuntungan bagi pemegang saham, tidak kepada masyarakat. Castello \& Lima (2006) menyatakan bahwa CSR berkaitan dengan isu-isu etika dan moral tentang bagaimana perusahaan membuat keputusan dan bersikap dan, selain itu, membahas isu-isu kompleks seperti perlindungan lingkungan, manajemen sumber daya manusia, kesehatan dan keselamatan di tempat kerja, masyarakat ikatan lokal, dan hubungan dengan pemasok dan pelanggan.

Penelitian in bertujuan untuk menganalisis apakah luas pengungkapan CSR memengaruhi hubungan antara mekanisme GCG dalam hal ini kepemilikan institusional dan kepemilikan manajerial terhadap nilai perusahaan.

\section{PENGEMBANGAN HIPOTESIS}

Manajer akan selalu berusaha untuk ikut menaikan nilai perusahaan dan akan berdampak pada nilai saham mereka, dimana, manajer akan ikut memperoleh manfaat langsung atas keputusankeputusan yang diambilnya, namun juga akan menanggung resiko secara langsung bila keputusan itu salah. Kepemilikan saham oleh manajer atau insider merupakan insentif untuk meningkatkan kinerja perusahaan. Soliha \& Taswan (2002), Leland \& Pyle (1977) menemukan bahwa insider ownership berpengaruh positif dan signifikan terhadap nilai perusahaan. Dari penemuan tersebut, maka rumusan hipotesis adalah:
$\mathrm{H}_{1}$ : kepemilikan manajerial berpengaruh positif terhadap nilai perusahaan

Melalui kepemilikan institusional, maka mekanisme dan monitoring akan terjadi sangat intens, hal ini disebabkan investor institusional terlibat dalam pengambilan yang strategis sehingga manipulasi laba sangat sulit dilakukan. Penelitian Ridwan \& Gunardi (2013), Rajgopal et al., (1999), Steiner (1996) dalam Suranta \& Machfoedz (2003) memberikan bukti bahwa kepemilikan institusional dan nilai perusahaan (Tobin's Q) memiliki hubungan yang signifikan. Maka rumusan hipotesis adalah: 
$\mathrm{H}_{2}$ : kepemilikan institusional berpengaruh positif terhadap nilai perusahaan.

Perusahaan akan terdorong untuk melaksanakan praktik dan pengungkapan CSR karena memperoleh beberapa manfaat (Solihin, 2009). Wahyudin (2008) menyatakan bahwa nilai perusahaan yang dibentuk melalui indikator nilai pasar saham, sangat dipengaruhi oleh peluang investasi. Retno \& Priantinah (2012) menyatakan GCG dan Pengungkapan CSR berpengaruh positif terhadap nilai perusahaan. Penelitian Choi (1998) menyatakan bahwa hubungan profitabilitas dan pengungkapan CSR merupakan isu kontroversial untuk dipecahkan. Namun Lajili \& Zeghal (2006) menemukan bahwa perusahaan yang lebih banyak mengungkapkan informasi human capital memiliki kinerja keuangan yang lebih baik dibandingkan dengan perusahaan yang sedikit mengungkapkan informasi tersebut. Penelitian (Gray et al., 1987; Parsa \& Kouhy, 1994; Becchetti et al., 2007) menunjukkan bahwa terdapat hubungan antara pengungkapan sosial dengan profitabilitas.

$\mathrm{H}_{3}$ : luas pengungkapan Corporate Social Responsibility berpengaruh positif terhadap nilai perusahaan

Manajer perusahaan akan mengungkapkan informasi sosial dalam rangka untuk meningkatkan image perusahaan, meskipun harus mengorbankan sumber daya untuk aktivitas tersebut. Penelitian Hidayah (2010), menemukan bahwa pengungkapan CSR tidak mampu memoderasi hubungan antara corporate governance terhadap kinerja perusahaan. Namun, penelitian Nasir \& Abdullah (2004) yang menunjukkan hasil signifikan positif. Dengan asumsi, bahwa penerapan CSR perusahaan akan memperoleh legitimasi sosial dan memaksimalkan kekuatan keuangannya dalam jangka panjang (Kiroyan, 2006).
$\mathrm{H}_{4}$ : luas pengungkapan CSR berpengaruh positif terhadap hubungan antara kepemilikan manajerial dengan nilai perusahaan.

Penelitian Ali et al. (2007), menyatakan bahwa kepemilikan perusahaan oleh institusi akan mendorong pengawasan yang lebih efektif, karena institusi merupakan profesional yang memiliki kemampuan dalam mengevaluasi kinerja perusahaan. Hal itu berarti dengan adanya kepemilikan institusional segala tindakan manajer akan diawasi oleh kepemilikan Institusional dan dapat mendorong kualitas dan kuantitas pengungkapan CSR. Sesuai dengan signalling theory yang menyatakan bahwa pengungkapan CSR merupakan sinyal positif bagi investor dalam melakukan investasi, karena penciptaan nilai pemangku kepentingan dapat dipandang sama dengan menciptakan nilai pemegang saham (Warsono, 2009). Namun, Triyono \& Setyadi (2015) menyatakan bahwa CSR tidak terpengaruh secara signifikan terhadap nilai perusahaan.

$\mathrm{H}_{5}$ : luas pengungkapan CSR berpengaruh terhadap hubungan antara kepemilikan institusional dengan nilai perusahaan.

\section{METODE}

Populasi penelitian ini adalah semua perusahaan sektor manufaktur yang terdaftar di Bursa Efek Indonesia (BEI). Pemilihan perusahaan pada sektor manufaktur sebagai objek penelitian karena: (1) Perusahaan manufaktur memiliki sensitivitas dan pengaruh yang tinggi terhadap masyarakat dan lingkungan sekitarnya; (2) Agar adanya persamaan dalam laporan keuangan, karena setiap laporan keuangan atau klasifikasi rekening pada setiap sektor terdapat penyajian yang berbeda. (3) Adanya perbedaan item pengungkapan di setiap sektor (Sembiring, 2005). Periode pengamatan penelitian dilakukan dari tahun 2012-2014. Perusahaan yang menjadi sampel dalam penelitian ini 


\section{Jurnal Keuangan dan Perbankan | KEUANGAN}

Vol. 21, No. 2, April 2017: 276-286

dipilih berdasarkan kiteria-kriteria tertentu (purposive sampling), yaitu: (1) Perusahaan terdaftar dalam sektor manufaktur tahun 2012 dan 2014; (2) Annual report perusahaan yang dapat diakses melalui website; (3) Perusahaan memiliki kepemilikan intitusional dan kepemilikan manajerial; (4) Perusahaan sampel mengungkapkan CSR; (5) Perusahaan sampel memiliki semua data yang diperlukan secara lengkap.

Tabel 1. Definisi Operasional dan Pengukuran Variabel

\begin{tabular}{lll}
\hline \multicolumn{1}{c}{ Variabel bebas (Independent Variable) } & & \\
\hline \multicolumn{1}{c}{ Variabel } & \multicolumn{1}{c}{ Definisi } & Rumus \\
\hline Kepemilikan & Kepemilikan saham oleh manajemen perusahaan & \% kepemilikanmanajerial \\
Manajerial & yang diukur dengan persentase jumlah saham yang & $=\frac{\text { Jumlah saham manajemen }}{\text { Jumlah saham yang beredar }}$ \\
& dimiliki oleh manajemen terhadap jumlah saham & \\
Kepemilikan & yang beredar (Sujono \& Soebiantoro, 2007) & \% kepemilikan institusional \\
Institusional & Kepemilikan saham oleh pemerintah, institusi & Jumlah saham Institusional \\
& keuangan, institusi berbadan hukum, institusi luar & $=\frac{\text { Jumlah saham yang beredar }}{\text { negeri, dana perwalian serta institusi lainnya pada }}$ \\
& akhir tahun (Putri \& Nasir, 2006) &
\end{tabular}

Variabel Terikat (Dependent Variable)

Nilai Perusahaan

Penentuan ukuran-ukuran tertentu yang dapat

mengukur keberhasilan suatu perusahaan dalam menghasilkan laba (Sucipto, 2003)

Tobin's $Q=\frac{(M V E+P S+D E B T)}{T A}$

Tobin's $Q$ dihitung dengan menggunakan rumus yang dikembangkan oleh Chung \& Pruitt (1994) saham biasa yang beredar.

MVE = harga penutupan saham di

Tobin's Q digunakan untuk mengukur variabel cara PS = nilai likuidasi dari saham kerja pasar perusahaan karena memiliki pengukuran preferen yang beredar.

yang komprehensive yaitu dengan melampirkan DEBT $=$ (utang lancar-aktiva

harga pasar dari utang (DEBT), saham (MVE) dan lancar)+nilai buku sediaan+utang nilai buku total aktiva (TA), (Andayani et al., 2008). jangka panjang. $\mathrm{TA}=$ nilai buku total aktiva

$$
\begin{aligned}
& \text { Tobin's } Q=\frac{(M V E+D E B T)}{T A} \\
& \text { (Klepper \& Love, 2002) dalam } \\
& \text { Dharmawati (2005) }
\end{aligned}
$$

\begin{tabular}{|c|c|c|}
\hline Moderating Variable & & \\
\hline $\begin{array}{l}\text { Pengungkapan } \\
\text { Corporate Social } \\
\text { Responsibility (CSR) }\end{array}$ & $\begin{array}{l}\text { Pengungkapan kinerja lingkungan, sosial, } \\
\text { dan ekonomi di dalam laporan tahunan } \\
\text { atau laporan terpisah adalah untuk } \\
\text { mencerminkan tingkat akuntabilitas, } \\
\text { responsibilitas, dan transparansi korporat } \\
\text { kepada investor dan stakeholders lainnya } \\
\text { (Novita \& Djakman, 2008). Pengungkapan } \\
\text { CSR di ukur dengan melakukan checklist } \\
\text { pada laporan CSR perusahaan yang } \\
\text { terdapat pada laporan tahunan } \\
\text { perusahaaan. Kategori yang menjadi acuan } \\
\text { yaitu kategori yang digunakan oleh } \\
\text { Hakston \& Milne (1996), yaitu: lingkungan, } \\
\text { energi, keselamatan dan kesehatan } \\
\text { karyawan, lain-lain tenaga kerja, produk, } \\
\text { keterlibatan dengan masyarakat dan } \\
\text { umum. }\end{array}$ & $\begin{array}{l}\text { Berdasarkan peraturan Bapepam No. VIII.G.2 } \\
\text { tentang laporan tahunan. Secara total terdapat } \\
78 \text { item pengungkapan (Sembiring, 2005). } \\
\qquad \text { CSRIj }=\frac{\sum X \mathrm{Xij}}{n} \\
\text { CSRIj: Corporate Social Responsibility Disclosure } \\
\text { Index perusahaan } \mathrm{j} \\
\mathrm{n}=\text { Jumlah item untuk perusahaan j, nj } \leq 78 \\
\text { Xij = dummy variable: } 1=\mathrm{jika} \text { item i } \\
\text { diungkapkan; } 0=\text { jika item i tidak di } \\
\text { ungkapkan. }\end{array}$ \\
\hline
\end{tabular}


Variabel dependen pada penelitian, yaitu GCG diproksikan dengan kepemilikan manajerial dan kepemilikan institusional dan variabel independen dengan nilai perusahaan, variabel pemoderasi menggunakan CSR.

Pengujian efek moderasi dan efek utama di riset dilakukan dengan menggunakan hierarchical regression analysis, dengan persamaan sebagai berikut:

$\mathbf{Y}=\alpha+\beta_{1} \mathrm{MNJ}+\beta_{2} \mathrm{INST}+\beta_{3} \mathrm{CSRI}$

$\mathbf{Y}=\alpha+\beta_{1} \mathrm{MNJ}+\beta_{2} \mathrm{INST}+\beta_{3} \mathrm{CSRI}+\beta_{4} \mathrm{MNJ}{ }^{*} \mathrm{CSRI}$

$\beta_{5}$ INST $^{*}$ CSRI $+\mathrm{e}$

Keterangan:

$\begin{array}{ll}\text { CSRI } & =\text { luas pengungkapan CSR } \\ \text { Tobin's Q } & =\text { nilai perusahaan } \\ \text { MNJ } & =\text { kepemilikan manajerial } \\ \text { INST } & \text { kepemilikan institusional } \\ \text { CSRI } & =\text { luas pengungkapan CSR } \\ \text { MNJ*CSRI }= & \text { interaksi kepemilikan manajerial- } \\ & \text { luas pengungkapan CSR, diukur } \\ & \text { dari perkalian MNJ dan CSRI } \\ \text { INST }{ }^{*} \text { CSRI }= & \text { interaksi kepemilikan manajerial- } \\ & \text { luas pengungkapan CSR, diukur } \\ & \text { dari perkalian INSTdan CSRI } \\ \alpha & =\text { konstanta } \\ \beta_{1 \ldots} \beta_{5} & =\text { koefisien regresi } \\ \mathrm{e} & =\text { error } / \text { variabel pengganggu }\end{array}$

\section{HASIL}

\section{Hasil Uji Normalitas Data}

Berdasarkan hasil uji normalitas dengan uji Kolmogorov-Smirnov maka besarnya nilai KolmogorovSmirnov adalah 1,245 dan signifikan pada 0,090 (p $=0,090)$ dan tidak signifikan pada 0,05 ( $>>0,05)$, maka dapat disimpulkan bahwa residual berdistribusi normal, Pengujian normalitas juga dilakukan untuk menguji model dua. Berdasarkan uji Kolmogorov-Smirnov pada model dua, nilai Z sebesar 0,808 dengan tingkat signifikansi 0,531 , hal ini menunjukkan bahwa model regresi mempunyai pola distribusi data normal karena tingkat sig- nifikansinya $\geq 0,05$, sehingga uji statistik parametrik dapat digunakan untuk menguji penelitian.

\section{Hasil Uji Multikolinearitas}

Uji multikolinearitas dapat dilakukan dengan melihat nilai Tolerance dan Value Inflation Factor (VIF). Berdasarkan hasil uji Multikolinearitas, model 1 menunjukkan bahwa tidak terjadi multikoliearitas pada variabel independen dalam penelitian ini. Hal itu terbukti dari nilai Tolerance variabel CSRI $(0,616), \operatorname{MNJ}(0,616)$ dan INST $(0,687)$ $>0,10$ dan nilai VIF masing masing variabel independen dalam penelitian< 10 , yaitu CSRI $(1,145)$, MNJ $(1,623)$ dan INST $(1,456)$. Pada model regresi 2 , dapat diketahui terjadi pelanggaran asumsi multikolinearitas, hal ini dapat dilihat dari beberapa variabel independen yang memiliki nilai tolerance $<0.1$ yaitu MNJ $(0,022)$, INST $(0,117)$, CSRI $(0,058)$, MNJCSRI $(0,023)$, MNJINST $(0,041)$ dan VIF $>10$ yaitu MNJ $(45,666)$, INST $(8,562)$, CSRI $(17,321)$, MNJCSRI $(43,431)$, MNJINST $(24,365)$. Namun, karena model regresi kedua ini menggunakan variabel pemoderasi hal ini tidak menjadi masalah karena multikolinearitas pada model regresi 2 bersumber dari variabel-variabel efek utama dan efek interaksi. Hartono (2009) memberikan argumentasi bahwa multikolinearitas tidak terjadi karena koefisien dari interaksi tidak sensitif terhadap perubahan dari titik awal skala dari variabel independen dan variabel pemoderasi, sehingga multikolinearitas tidak terjadi masalah ketika menetapkan analisis regresi moderasi.

\section{Hasil Uji Heteroskedastisitas}

Hasil penelitian pada uji heteroskedastisitas, menunjukkan bahwa titik-titik menyebar secara acak serta tersebar baik diatas maupun dibawah angka 0 pada sumbu Y. Hal ini dapat disimpulkan bahwa tidak terjadi heterokedastisitas pada model 1 dan model 2, sehingga model regresi layak dipakai dalam penelitian ini. 


\section{Jurnal Keuangan dan Perbankan | KEUANGAN}

Vol. 21, No. 2, April 2017: 276- 286

\section{Hasil Uji Autokorelasi}

Pengujian ini dilakukan untuk menguji apakah dalam suatu model regresi linier ada korelasi antara kesalahan pengguna pada periode $t$ dengan kesalahan pada periode t-1 (Ghozali, 2005). Berdasarkan output SPSS model 1 bahwa nilai DurbinWatson dengan jumlah observasi $(\mathrm{N})=44$ dan jumlah variabel independen $2(\mathrm{k}=2)$ diperoleh nilai tabel dl (lower) $=1,338$ dan du (upper) $=1,659$. Oleh karena nilai $\mathrm{DW}=1,858$ maka tidak terjadi autokorelasi positif maupun negatif. Berdasarkan outputSPSS model 2 bahwa nilai durbin-watson dengan jumlah observasi $(\mathrm{N})=44$ dan jumlah variabel independen $5(\mathrm{k}=5)$ diperoleh nilai tabel dL (lower) $=1,230$ dan $\mathrm{dU}$ (upper) $=1,786$. Oleh karena nilai $\mathrm{DW}=1,866$ maka tidak terjadi auto korelasi positif maupun negatif dalam penelitian ini.

\section{Pengujian Model 1}

Tabel 2. Hasil Uji Regresi Model 1

\begin{tabular}{lccc}
\hline \multirow{2}{*}{ Model } & \multicolumn{2}{c}{$\begin{array}{c}\text { Unstandardized } \\
\text { Coefficients }\end{array}$} & \multirow{2}{*}{ Sig. } \\
\cline { 2 - 3 } & B & Std. Error & \\
\hline Constant & $-0,787$ & 0,546 & 0,158 \\
CSRI & 2,524 & 1,559 & 0,114 \\
MNJ & 7,695 & 3,151 & 0,019 \\
INST & 1,642 & 0,583 & 0,008 \\
\hline
\end{tabular}

Berdasarkan hasil analisis regresi yang disajikan dalam Tabel 2 maka dapat dituliskan regresi model pertama sebagai berikut:

$\mathrm{Y}=-0,787+2,524 \mathrm{MNJ}+7,695 \mathrm{INST}+1,642 \mathrm{CSRI}$

Nilai konstanta sebesar $-0,787$ yang berarti bahwa jika tidak ada variabel bebas atau independen yang memengaruhi nilai perusahaan maka nilai perusahaan akan sebesar - 0,787 atau nilai perusahaan mengalami kerugian. Nilai kepemilikan manajerial adalah sebesar 2,524 menunjukkan bahwa jika nilai perusahaan meningkat sebesar satu satuan, maka kepemilikan manajerial akan ikut meningkat sebesar 2,524. Nilai kepemilikan manajerial adalah sebesar 7,695 menunjukkan bahwa jika nilai perusahaan meningkat sebesar satu satuan, maka kepemilikan institusional akan ikut meningkat sebesar 7,695. Nilai indeks CSR adalah sebesar 1,642 menunjukkan bahwa jika nilai perusahaan meningkat sebesar satu satuan, maka kepemilikan Institusional akan ikut meningkat sebesar 1,642.

Hasil uji hipotesis 1 memenuhi kedua kriteria penerimaan hipotesis yaitu besar $t_{\text {hitung }}$ hasil outputSPSS pada variabel kepemilikan manajerial adalah sebesar 2,442 sedangkan $\mathrm{t}_{\text {tabel }}(\alpha=5 \%, \mathrm{dk}=44$ $1=43$ ) adalah sebesar 1,684, maka hal itu menunjukkan $t_{\text {hitung }}>t_{\text {tabel }}$. Besarnya nilai $p=0,019$. Jika dalam pengujian hipotesis ini dipakai tingkat signifikansi $\alpha=0,05$ maka nilai $p(0,019)<\alpha(0,05)$. Dapat disimpulkan bahwa hipotesis 1 adalah signifikan, kepemilikan manajerial berpengaruh positif terhadap nilai perusahaan. Hasil uji hipotesis 2 penelitian ini menunjukkan bahwa kepemilikan institusional berpengaruh positif dan signifikan terhadap nilai perusahaan. Hal tersebut ditunjukkan dengan nilai $t_{\text {tabel }}$ sebesar 1,684 dan $t_{\text {hitung }}$ sebesar 2,817 sehingga nilai $t_{\text {hitung }}>t_{\text {tabel }}$. Sedangkan nilai $p$ $(0,019)<a ́(0,05)$. Hasil yang positif dan tidak signifikan terjadi pada hipotesis 3 yang menyatakan bahwa luas pengungkapan CSR berpengaruh positif terhadap nilai perusahaan. Hal ini berarti luas pengungkapan CSR tidak mampu atau gagal menjadi mekanisme peningkatan nilai perusahaan.

\section{Pengujian Model 2}

Tabel 3. Hasil Uji Regresi Model 2

\begin{tabular}{lrrr}
\hline \multirow{2}{*}{ Model } & \multicolumn{2}{c}{ Unstandardized } & \multirow{2}{*}{ Coefficients } \\
\cline { 2 - 3 } & \multicolumn{1}{c}{ S } & Std. Error \\
(Constant) & $-0,412$ & 0,911 & 0,654 \\
MNJ & $-34,250$ & 15,556 & 0,034 \\
INST & 1,166 & 1,316 & 0,382 \\
CSRI & 0,494 & 5,643 & 0,931 \\
MNJCSRI & 380,986 & 139,641 & 0,010 \\
INSTCSRI & 2,087 & 8,699 & 0,812 \\
\hline
\end{tabular}


Berdasarkan hasil analisis regresi yang disajikan dalam Tabel 3 maka dapat dituliskan model regresi model kedua sebagai berikut: $\mathrm{Y}=-0,412-34,250 \mathrm{MNJ}+1,166 \mathrm{INST}+0,494 \mathrm{CSRI}+$ 380,986 MNJ*CSRI+ 2,087 INST*CSRI + e

Nilai konstanta sebesar $-0,412$ yang berarti bahwa jika tidak ada variabel bebas atau independen, interaksi variabel kepemilikan manajerial dengan indeks CSR dan interaksi variabel kepemilikan institusional dengan indeks CSR yang memengaruhi nilai perusahaan maka nilai perusahaan akan sebesar -0,412 atau nilai perusahaan mengalami kerugian. Nilai kepemilikan manajerial adalah sebesar 380,986 menunjukkan bahwa jika nilai perusahaan meningkat sebesar satu satuan, maka kepemilikan Manajerial akan ikut meningkat sebesar 380,986. Nilai kepemilikan manajerial adalah sebesar 2,087 menunjukkan bahwa jika nilai perusahaan meningkat sebesar satu satuan, maka kepemilikan institusional akan ikut meningkat sebesar 2,087.

Hasil uji hipotesis 4 menunjukkan bahwa luas pengungkapan CSR berpengaruh positif dan signifikan terhadap hubungan antara kepemilikan manajerial dengan nilai perusahaan. Hal tersebut terlihat dari nilai $t_{\text {hitung }}$ sebesar 2,728 dan $_{t_{\text {tabel }}}$ sebesar 1,684 sehingga $t_{\text {hitung }}>t_{\text {tabel }}$, dan nilai $p(0,01)<\alpha$ $(0,05)$. Penolakan hipotesis kembali terjadi pada hipotesis 5, hasil SPSS menunjukkan hasil yang positif, namun tidak signifikan, sehingga dapat disimpulkan bahwa luas pengungkapan CSR belum mampu memoderasi hubungan antara kepemilikan institusional dengan nilai perusahaan. Hasil yang tidak signifikan ditunjukkan oleh nilai $\mathrm{p}(0,812)>$ $\alpha(0,05)$.

\section{Hasil Uji F}

Hasil uji F model 1 menunjukkan nilai $\mathrm{F}_{\text {hitung }}$ sebesar 3,292 dengan tingkat signifikansi 0,031. Karena nilai signifikansi lebih kecil dari nilai $\alpha=$
0,05, maka model regresi dapat digunakan untuk memprediksi nilai perusahaan atau dapat dikatakan bahwa variabel kepemilikan manajerial, kepemilikan institusional dan luas pengungkapan CSR secara bersama-sama berpengaruh terhadap nilai perusahaan. Hasil uji Anova atau F test untuk model 2 juga menunjukkan bahwa model regresi 2 dapat digunakan untuk memprediksi nilai perusahaan. hal itu dibuktikan dengan hasil output SPSS yang menunjukkan tingkat signifikansi 0,007 jauh di bawah nilai $\alpha=0,05$. Jadi dapat disimpulkan variabel kepemilikan manajerial, kepemilikan institusional secara bersama-sama berpengaruh terhadap nilai perusahaan.

\section{Uji Koefisien Determinasi}

Hasil penelitian model 1 besarnya adjusted $\mathrm{R}^{2}$ sebesar 0,147 . Hal ini berarti $14,7 \%$ variasi nilai perusahaan yang dapat dijelaskan oleh variasi variabel independen kepemilikan manajerial, kepemilikan institusional dan luas pengungkapan CSR, sedangkan sisanya 85,3\% dijelaskan oleh variabel-variabel lain di luar model. Output SPSS model 2 menunjukkan besarnya nilai Adjusted $\mathrm{R}^{2}$ sebesar 0,261 . Hal ini berarti $26,1 \%$ variasi nilai perusahaan dapat dijelaskan oleh variasi variabel independen kepemilikan manajerial, kepemilikan institusional, dan luas pengungkapan CSR sedangkan sisanya 73,9\% dijelaskan oleh variabel lain di luar model.

\section{PEMBAHASAN}

Hasil penelitian menunjukkan bahwa kepemilikan manajerial berpengaruh positif terhadap kinerja perusahaan. Hasil penelitian ini sesuai dengan Soliha \& Taswan (2002), yang menemukan bahwa insider ownership berpengaruh positif dan signifikan terhadap nilai perusahaan. Hasil penelitian berikutnya adalah kepemilikan institusional berpengaruh positif dan signifikan terhadap kinerja perusahaan. Machfoedz (2003) memberikan bukti 


\section{Jurnal Keuangan dan Perbankan | KEUANGAN}

Vol. 21, No. 2, April 2017: 276-286

bahwa kepemilikan institusional dan kinerja perusahaan (Tobin's Q) memiliki hubungan yang signifikan. Hasil penelitian berikutnya yang menyatakan luas pengungkapan CSR berpengaruh positif terhadap kinerja perusahaan bertolak belakang dengan teori. Hal ini dikarenakan nilai rata-rata indeks CSR masih sangat kecil, yaitu hanya 15,6\% atau sekitar 12 item pengungkapan dari 78 item pengungkapan yang disarankan. Sehingga hal ini mengindikasikan bahwa pengungkapan CSR belum bisa menjelaskan brand image dalam rangka meningkatkan daya tarik perusahaan dimata investor.

Hasil penelitian berikutnya yang menunjukkan semakin besar kepemilikan manajer di dalam sebuah perusahaan, maka akan semakin produktif tindakan manajer dalam memaksimalkan nilai perusahaan. Manajer akan berusaha untuk membentuk brand image yang "cantik" dan beretika. Dengan itu, ketertarikan investor akan semakin tinggi, yang pada akhirnya akan meningkatkan nilai perusahaan sekaligus peningkatan kesejahteraan manajer sesuai dengan proporsi kepemilikannya. Hal tersebut sejalan dengan pernyataan Nasir \& Abdullah (2004), Kiroyan, (2006). Hasil penelitian ini menunjukkan bahwa luas pengungkapan CSR belum mampu memoderasi hubungan antara kepemilikan institusional dengan nilai perusahaan. Hasil penelitian ini konsisten dengan penelitian Hidayah (2010).

\section{SIMPULAN DAN SARAN}

\section{Simpulan}

Penelitian in bertujuan untuk menganalisis apakah luas pengungkapan CSR memengaruhi hubungan antara mekanisme GCG dalam hal ini kepemilikan Institusional dan kepemilikan Manajerial terhadap nilai perusahaan. Hasil penelitian menunjukkan bahwa terdapat hubungan yang positif dan signifikan antara mekanisme GCG dengan nilai perusahaan, sedangkan antara luas pengungkapan CSR dengan nilai perusahaan ditemukan hasil yang tidak signifikan. Untuk pengujian efek-efek mode- rasi, luas pengungkapan CSR berhasil memoderasi hubungan antara kepemilikan manajaerial dengan kinerja perusahaan, namun luas pengungkapan CSR tidak berhasil memoderasi hubungan antara kepemilikan institusional dengan nilai perusahaan. Keterbatasan penelitian, kecilnya indeks CSR dikarenakan oleh ketidak adanya standar akan menimbulkan intepretasi yang berbeda-beda hal ini tentu bisa menjadi kontraproduktif dalam upaya menciptakan pemahaman yang sama mengenai pengungkapan CSR.

\section{Saran}

Perusahaan manufaktur yang telah melaksanakan GCG dengan baik seharusnya melaksanakan aktivitas CSR. Sehingga perusahaan perlu mengembangkan sejumlah kebijakan untuk menuntun pelaksanaan CSR. Semua hal tersebut tidak terlaksana dengan baik apabila perusahaan tidak menerapkan GCG beserta aspek-aspek yang termasuk di dalamnya. Kecilnya indek CSR disebabkan karena pemilihan sampel penelitian pada sektor yang kurang tepat. UU No. 40 tahun 2007 disebutkan bahwa perseroan yang wajib melaksanakan tanggung jawab sosial dan lingkungan adalah perseroan yang menjalankan kegiatan usahanya di bidang dan/atau berkaitan dengan sumber daya alam. Sehingga untuk penelitian selanjutnya, disarankan memilih sektor Minning and Minning Service yang lebih banyak memanfaatkan sumber daya alam dalam kegiatan bisnisnya. Penelitian ini diharapkan dapat berkontribusi pada pengembangan teori dalam bidang keuangan, khususnya mengenai hubungan antara nilai perusahaan, pengungkapan CSR dan GCG. Bagi dunia praktik penelitan ini berguna bagi para pelaku bisnis dalam mengetahui arti penting dari konsep Tripple Bottom Line dalam aktivitas bisnis, dan dampaknya bagi nilai perusahaan serta bagi para pemakai laporan keuangan. 


\section{DAFTAR PUSTAKA}

Andayani, W., Atmini, S., Sadewo, D., \& Mwangi, J.K. 2008. Corporate Social Responsibility, Good Corporate Governance and The Intellectual Property: An External Strategy of The Management to Increase The Company's Value. National Conference on Management Research, Makassar 27 November 2008.

Becchetti, L., Ciciretti, R., \& Hasan, I. 2007. Corporate Social Responsibility and Shareholder's Value: An Event Study Analysis. Working Paper. Series Federal Reserve Bank of Atlanta.

Ali, C.B., Summa, M., \& Trabelsi, S. 2007. Disclosure Quality and Ownership Structure: Evidence from the French Stock Market. Corporate Ownership and Control, 5(2).

Castello, M., \& Lima, L. 2006. Corporate Social Responsibility and Resource-Based Perspective. Journal of Business Ethics, 69(2): 111-132.

Chapple, W. \& Moon, J. 2005. Corporate Social Responsibility (CSR) in Asia: A Seven-Country Study of CSR Situs Site Reporting Chicago, 44(4): 415-442.

Choi, J. 1998. An Evaluation of the Voluntary Corporate Environmental Disclosures: A Korean Evidence. Social and Environmental Accounting, 18(1): 2-7.

Chung, K.H. \& Pruitt, S.W. 1994. A Simple Approximation of Tobin's q. Financial Management, 23(3): 7074 .

Daniri, M.A. 2005. Good Corporate Governance, Konsep dan Penerapannya dalam Konteks Indonesia. Jakata: PT RayIndonesia.

Daniri, M.A. 2009. Penerapan Good Corporate Governance bagi Perusahaan Efek. Jakata: Koran Tempo, 17 Maret 2009. http://koran.tempo.co/2009/03/18.

Darwin, A. 2006. Akuntabilitas, Kebutuhan, Pelaporan dan Pengungkapan CSR bagi Perusahaan di Indonesia. IAI-KAM, E-BAR (3): September-Desember.

Deegan, C. \& Rankin, M. 1996. Do Australian Companies Report Environmental News Objectively? An Analysis of Environmental Disclosures Firms Prosecuted Successfully by the Environmental Protection Authority. Accounting Auditing and Accountability Journal, 9(2): 50-68.
Ebert, R.J. \& Griffin, R.W. 2003. Bisnis. Edisi Keenam. Jilid I. Alih Bahasa Edina Cahyaning Tarmidzi. Jakarta: Prenhallindo.

Freeman, R. E. 1984. Strategic Management: A Stakeholder Approach. Boston: Pitman Publishing.

Ghozali, I. 2005. Aplikasi Analisis Multivariate dengan Program SPSS. Semarang: Universitas Diponegoro.

Gray, R., Owen, D., \& Maunders, K. 1987. Corporate Social Reporting: Accounting and Accountability. London: Prentice-Hall.

Hartono, J. 2009. Metodologi Penelitian Bisnis: Salah Kaprah dan Pengalaman-Pengalaman. Yogyakarta: BPFE.

Hidayah, E. 2010. Pengaruh Kualitas Pengungkapan Informasi terhadap Hubungan antara Penerapan Corporate Governance dengan Kinerja Perusahaan di Bursa Efek Jakarta. JAAI, 12(1): 5364.

Jensen, M.C. \& Meckling, W.H. 1976. Theory of The Firm: Managerial Behavior, Agency Cost and Ownership Structure. Journal of Financial Economics 3(4): 305-360.

Kampf, C. 2007. Corporate Social Responsibility WaltMart, Maersk and the Cultural Bounds of Representation in Corporate Situs Sites, 12(1): 4157.

Kawatu, F.S. 2009. Mekanisme Corporate Governance terhadap Nilai Perusahaan dengan Kualitas Laba sebagai Variabel Intervening. Jurnal Keuangan dan Perbankan, 13(3): 405-417.

Kiroyan, N. 2006. Good Corporate Governance (GCG) dan Corporate Social Responsibility (CSR) Adakah Kaitan Diantara Keduanya? Economics Business Accounting Review, III: 45-58.

Lajili, K. \& Zeghal, D. 2006. Market Performance Impacts on Human Capital Disclosures. Journal of Accounting and Public Policy, 25(2): 171-194.

Leland, H. \& Pyle, D.H. 1977. Informational Asymmetries, Financial Structure and Financial Intermediation, Journal of Finance, 32(2): 371-387.

Nasir, M.N.A \& Abdullah, S.N. 2004. Voluntary Disclosure and Corporate Governance among Financially Distressd Firm in Malaysia, Financially Reporting, Regulation and Governance, 3(1): 1-39. 


\section{Jurnal Keuangan dan Perbankan | KEUANGAN}

Vol. 21, No. 2, April 2017: 276-286

Novita \& Djakman, C.D. 2008. Pengaruh Struktur Kepemilikan terhadap Luas Pengungkapan Tanggung Jawab Sosial (CSR Disclosure) pada Laporan Tahunan Perusahaan; Studi Empiris pada Perusahaan Publik yang Tercatat di Bursa Efek Indonesia tahun 2006. Prosiding. Simposium Nasional Akuntansi XI, Pontianak, 22 - 25 Juli.

Parsa, S. \& Kouhy, R. 1994. Disclosure of Social Information by UK Companies; a Case Study of Legitimacy Theory. www.ssrn.com. Diakses tanggal 17 November 2010.

Putri, I.F., \& Nasir, M. 2006. Analisis Persamaan Simultan Kepemilikan Manajerial, Kepemilikan Institusional, Risiko, Kebijakan Hutang dan Kebijakan Dividen dalam Perspektif Teori Keagenan. Prosiding. Simposium Nasional Akuntansi 9 Padang, 23-26 Agustus.

Rajgopal, S., Venkatachalam, M., \& Jiambalvo, J. 1999. Is Institutional Ownership Associated with Earnings Management and the Extent to which Stock Prices Reflecy Future Earnings? Working Paper. University of Washington, Seattle. May.

Retno, R.D. \& Priantinah, D. 2012. Pengaruh Good Corporate Governance dan Pengungkapan Corporate Social Responsibility terhadap Nilai Perusahaan (Studi Empiris pada Perusahaan yang Terdaftar di Bursa Efek Indonesia Periode 2007-2010). Jurnal Nominal, 1(1): 84-103.

Ridwan, M. \& Gunardi, A. 2013. Peran Mekanisme Corporate Governance sebagai Pemoderasi Praktik Earning Management terhadap Nilai Perusahaan. Trikonomika, 12(1): 49-60.

Ross, S.A., Westerfield, R. W., \& Jordan, B.D. 2001. Fundamentals of Corporate Finance, Alternate Fifth Edition. Essentials of Corporate Finance. Second Edition. The McGraw-Hill Companies, Inc.

Sandra, T.S. \& Akhmad, A. 2011. Pengaruh Karakteristik Perusahaan terhadap Pengungkapan Sosial (Social Disclosure) pada Perusahaan Manufaktur yang Terdaftar di BEI. Jurnal Ekonomi, 14(1).

Sembiring, E.R. 2005. Karakteristik Perusahaan dan Pengungkapan Tanggung Jawab Sosial: Studi Empiris pada Perusahaan yang Tercatat di Bursa Efek Jakarta. Prosiding Makalah Disampaikan dalam Simposium Nasional Akuntansi VIII. Solo, 15-16 September.
Shleifer, A. \& R.W. Vishny. 1997. A Survey of Corporate Governance. Journal of Finance, 52(2): 737-783.

Solihin, I. 2009. Corporate Social Responsibility from Charity to Sustainability. Jakarta: Salemba Empat.

Soliha, E. \& Taswan. 2002. Pengaruh Kebijakan Hutang terhadap Nilai Perusahaan serta Beberapa Faktor yang Memengaruhinya. Jurnal Bisnis dan Ekonomi, 9(2): 149-163.

Sucipto. 2003. Penilaian Kinerja Keuangan. FE Universitas Sumatera Utara.

Sujono \& Soebiantoro, U. 2007. Pengaruh Struktur Kepemilikan Saham, Leverage, Faktor Intern dan Faktor Ekstern Terhadap Nilai Perusahaan (Studi Empirik pada Perusahaan Manufaktur dan Non Manufaktur di Bursa Efek Jakarta). Jurnal Manajemen dan Kewirausahaan, 9(1): 43-47.

Suranta, E. \& Machfoedz, M. 2003. Analisis Struktur Kepemilikan, Nilai Perusahaan, Investasi dan Ukuran DewanDireksi. Simposium Nasional Akuntansi VI. Surabaya.

Thai Institute of Director. ASEAN CG Scorecard 2015. http:/ / www.thai-iod.com/en/publicationsdetail.asp?id=317. Diakses tanggal 8 Januari 2017.

Triyono, F. \& Setyadi, E. J. 2015. Pengaruh Good Corporate Governance, dan Pengungkapan Corporate Social Responsibility terhadap Nilai Perusahan pada Perusahaan Property and Real Estate yang di BEI. Jurnal Kompartemen, XIII(1).

Verrecchia, R. E. 1983. Discretionary Disclosure. Journal of Accounting and Economics, 5(3): 179-194.

Wahyudin, Z. 2008. Good Corporate Governance pada Badan Usaha Manufaktur, dan Jasa Keuangan Lainnya. Bandung: Alfabeta.

Warsono, S. 2009. Corporate Governance Concept and Model: Preserving True Organization Welfare. Yogyakarta: Center for Good Corporate Governance Fakultas Ekonomika dan Bisnis UGM. 